\title{
Pengaruh Ekstrak Rimpang Alang-alang (Imperata cylindrica L.) pada Bobot Kering dan Persen Penutupan Gulma
}

\section{(The Effect of Alang-alang [Imperata cylindrica L.] Rhizome Extraction Dry Weight of Weed and Percent of Weed Coverage)}

\author{
Argi Zhafran Tamin ${ }^{1 *}$, Dedi Supriyatdi ${ }^{2)}$, Mirodi Syofian ${ }^{2)}$ \\ ${ }^{1)}$ Program Studi Produksi dan Manajemen Industri Perkebunan Politeknik Negeri Lampung dan ${ }^{2)}$ \\ Jurusan Budidaya Tanaman Perkebunan, Politeknik Negeri Lampung Jl. Soekarno-Hatta No.10 \\ Rajabasa, Bandar Lampung, 35144, Telp.: (0721) 703995, Fax.: (0721) 787309 \\ E-mail: argizhafrantamin@gmail.com
}

\begin{abstract}
The use of herbicides has a negative impact on the environment so an environmentally friendly herbicide is needed. Alang-alang that are available in almost every area has a content of tannins in the form of allelopathy potential for weed control. The objective of the research is to know the percent of weed coverage due to the application of alang-alang bioherbicide. Concentration levels were tested in this research are: 5\%, 10\%, 15\%, and $20 \%$. The research was arranged in a randomized block design that has five replication. Variables observed were the dry weight of weeds and percent of weed coverage. The results of this research showed that all various concentrations have not affected in controlling weeds and percent of weed coverage.
\end{abstract}

Keywords: allelopathy, bioherbicide, weed control

Diterima: 15 Juli 2017 / Disetujui: 29 September 2017 / Diterbitkan: 15 Oktober 2017

\section{PENDAHULUAN}

Indonesia adalah negara dengan kekayaan sumberdaya yang melimpah sehingga Organisme Penganggu Tanaman (OPT) dengan mudahnya tumbuh dan berkembang. OPT pada tanaman dibagi menjadi tiga bagian yaitu: hama, penyakit dan gulma. Pada permasalahan ini perkembangan ilmu gulma paling lambat dibandingkan dengan hama dan penyakit dikarenakan dua alasan. Pertama, adanya perbedaan intensitas serangan yang ditunjukkan oleh ketiga kelompok tersebut. Hama dan penyakit sangat merugikan karena dalam waktu singkat dapat menggagalkan usaha tani. Kedua, gulma telah teratasi dengan adanya kultivasi atas pengolahan tanah karena pada saat budidaya bagian gulma akan terpotong dan terbenam dalam tanah (Sembodo, 2010).

Dua alasan di atas belum sepenuhnya mengatasi masalah gulma dalam pertanian. Sebagian petani belum menerapkan pengendalian gulma dengan baik. Tentunya ini akan merugikan produktivitas lahan petani setahap demi setahap karena adanya persaingan hara, air, cahaya, $\mathrm{CO}_{2}$ dan ruang tumbuh antara tanaman budidaya dengan gulma. Persaingan yang terjadi antara tanaman dan gulma dalam memperebutkan unsur hara mengakibatkan kerugian bagi tanaman budidaya, selain itu beberapa spesies gulma juga menghasilkan senyawa alelopat yang dapat merugikan pertumbuhan tanaman. Senyawa tersebut tidak hanya menekan pertumbuhan tanaman budidaya, 
tetapi juga dapat menekan pertumbuhan jenisgulma lainnya serta mampu menurunkan jumlah dan kualitas panen tanaman (Rahmawasiah, 2015).

Pengendalian dengan cara budidaya pun sebenarnya tidak efektif dalam beberapa aspek pertanian. Pengendalian ini hanya akan memperlambat sementara pertumbuhan gulma. Hal ini disebabkan simpanan biji gulma yang terpendam dalam tanah akibat pengolahan tanah dapat berkecambah dan tumbuh (Santosa et al., 2009). Selain biji, beberapa bagian gulma juga dapat menjadi calon tunas seperti rhizoma dan umbi (Sembodo, 2010).

Pengendalian gulma di perkebunan dapat dilakukan dengan beberapa metode yaitu: manual, mekanis, kultur teknis, biologis, metode kimiawi dengan herbisida atau menggabungkan beberapa metode sekaligus. Metode yang paling sering digunakan adalah metode dengan herbisida kimiawi karena dianggap paling cepat dan praktis dibandingkan dengan yang lainnya namun pengendalian dengan herbisida kimia mempunyai beberapa kekurangan seperti residu herbisida yang sulit terurai sehingga menimbulkan kematian pada beberapa predator alami. Oleh sebab itu maka harus ada hebisida yang ramah lingkungan seperti herbisda nabati.

Alang-alang banyak dijumpai di lahan terbuka maupun di lahan budidaya. Alang-alang mempunyai kandungan alelopat yang dapat mempengaruhi pertumbuhan tanaman. Senyawa fenol yang merupakan alelopati alang-alang dapat berfungsi sebagai bioherbisida kontak (Kamasurya, 2014; Syakir et al., 2008). Untuk mengetahui potensi alang-alang sebagai bioherbisida harus diketahui gulma-gulma yang tertekan oleh bioherbisida tersebut. Gulma yang tertekan oleh herbisida diketahui dengan perhitungan bobot kering tanaman dan persen penutupan gulma sehingga penelitian ini bertujuan untuk mengetahui seberapa besar bobot kering gulma dan persen penutupan gulma.

\section{METODE PENELITIAN}

Penelitian ini dilaksanakan di lahan praktikum dan penelitian Politeknik Negeri Lampung (Polinela) pada bulan Februari sampai dengan Maret 2016. Bahan dasar yang digunakan dalam penelitian ini adalah rimpang alang-alang dan air serta alat yang digunakan antara lain: sprayer, plang, erlenmayer, cangkul, saringan, blender, meteran, gelas beaker, dan ember. Penelitian ini dilaksanakan menggunakan Rancangan Acak Kelompok (RAK) yang terdiri atas 5 taraf konsentrasi: $0 \%, 5 \%, 10 \%, 15 \%$, dan $20 \%$ dengan ulangan sebanyak 5 kali sehingga terdapat 25 unit percobaan. 


\section{HASIL DAN PEMBAHASAN}

\section{Analisis Vegetasi Gulma}

Analisis vegetasi gulma sangat perlu dilakukan sebelum melaksanakan kegiatan penelitian. Menurut Sukman \& Yakup (2002), inventarisasi gulma sebelum tindakan pengendalian diperlukan untuk mengetahui jenis-jenis gulma dominan pada suatu ekosistem agar dapat diterapkan pengendalian yang efektif dan efisien

Hasil pengamatan analisis vegetasi gulma sebelum aplikasi bioherbisida ekstrak rimpang alang-alang diketahui ada 19 spesies gulma yang terdiri dari 11 spesies gulma berdaun lebar, 7 spesies gulma berdaun sempit dan 1 spesies gulma teki. Gulma-gulma tersebut adalah: (1) Ageratum conyzoides L., (2) Asystasia gangetica (L.) T. Anders, (3) Axonopus compressus (Sw.) P. Beauv., (4) Calopogonium mucunoides Desv., (5) Commelina benghalis L., (6) Cyperus kyllingia Endl., (7) Echinochloa colona (L.) Link, (8) Elephantropus scaber L., (9) Euphorbia hirta L., (10) Isotoma longiflora (L.) Presl., (11) Mimosa pudica L., (12) Otthochloa nodosa (Kunth) Dandy, (13) Oxalis barrelieri L., (14) Panicum dichotomiflorum Bergius., (15) Paspalum conjugatum Berg., (16) Phyllanthus niruri L., (17) Setaria plicata (Lamk.) T. Cooke, (18) Stachytarpheta indica (L.) Vahl, dan (19) Synedrella nodiflora (L.) Gaertn.

Pengamatan yang dilakukan selama 6 minggu setelah aplikasi menunjukkan adanya satu gulma yang sangat dominan yaitu A. gangetica . Hasil ini didapatkan dengan membandingkan ratarata nilai summed dominance ratio (SDR) setiap perlakuan. Selain A. gangetica yang memiliki nilai tebesar sebagai gulma yang paling dominan, dua gulma yang mempunyai nilai besar lain ialah $E$. scaber dan P. dichotomiflorum.

\section{Bobot Kering Gulma}

Berdasarkan hasil sidik ragam yang telah dilakukan, baik bobot kering sebelum aplikasi (0 MSA) maupun setelah aplikasi (1 MSA hingga 6 MSA) diketahui bahwa aplikasi bioherbisida ekstrak rimpang alang-alang tidak berpengaruh nyata pada bobot kering gulma 0-6 MSA (Tabel 1). Berdasarkan bobot kering gulma yang telah diamati diketahui bahwa tidak ada satupun dari perlakuan yang memberikan pengaruh. Hal ini diduga karena ekstrak rimpang alang-alang sampai dengan konsentrasi $20 \%$ tidak meracuni gulma sehingga tidak menimbulkan kerusakan pada jaringan/organ gulma ataupun mengganggu proses metabolisme gulma.

Kurangnya efektivitas keracunan ini didukung oleh penelitian Kamali (2014) yang bependapat bahwa ekstrak rimpang alang-alang (Imperata cylindrica L.) tidak berpotensi sebagai bioherbisida pada gulma rumput kerbau (Paspalum conjugatum Berg.) dan ekstrak rimpang alangalang tidak berpotensi dalam menghambat berat kering pada rumput kerbau. 
Tabel 1. Bobot kering gulma pada 0 MSA, 1 MSA, 2 MSA, 3 MSA, 4 MSA, 5 MSA, dan 6 MSA

\begin{tabular}{lccccccc}
\hline \multirow{2}{*}{ Perlakuan } & \multicolumn{7}{c}{ Bobot kering gulma $(\mathrm{g})$} \\
\cline { 2 - 8 } & 0 MSA & 1 MSA & 2 MSA & 3 MSA & 4 MSA & 5 MSA & 6 MSA \\
\hline $\mathrm{P}_{0}(0 \%)$ & $7,88^{\mathrm{a}}$ & $9,90^{\mathrm{a}}$ & $7,72^{\mathrm{a}}$ & $8,03^{\mathrm{a}}$ & $8,02^{\mathrm{a}}$ & $7,29^{\mathrm{a}}$ & $7,55^{\mathrm{a}}$ \\
$\mathrm{P}_{1}(5 \%)$ & $8,53^{\mathrm{a}}$ & $7,95^{\mathrm{a}}$ & $7,20^{\mathrm{a}}$ & $7,46^{\mathrm{a}}$ & $7,89^{\mathrm{a}}$ & $7,65^{\mathrm{a}}$ & $7,54^{\mathrm{a}}$ \\
$\mathrm{P}_{2}(10 \%)$ & $7,44^{\mathrm{a}}$ & $8,86^{\mathrm{a}}$ & $8,49^{\mathrm{a}}$ & $8,09^{\mathrm{a}}$ & $7,95^{\mathrm{a}}$ & $7,74^{\mathrm{a}}$ & $7,75^{\mathrm{a}}$ \\
$\mathrm{P}_{3}(15 \%)$ & $8,36^{\mathrm{a}}$ & $7,95^{\mathrm{a}}$ & $7,66^{\mathrm{a}}$ & $7,58^{\mathrm{a}}$ & $7,88^{\mathrm{a}}$ & $7,95^{\mathrm{a}}$ & $7,13^{\mathrm{a}}$ \\
$\mathrm{P}_{4}(20 \%)$ & $6,67^{\mathrm{a}}$ & $8,37^{\mathrm{a}}$ & $6,80^{\mathrm{a}}$ & $6,63^{\mathrm{a}}$ & $6,60^{\mathrm{a}}$ & $6,26^{\mathrm{a}}$ & $6,42^{\mathrm{a}}$ \\
\hline
\end{tabular}

Keterangan: Angka-angka pada kolom yang sama dan diikuti huruf yang sama menunjukkan tidak berbeda nyata pada Uji BNT 5\%

Tidak berpengaruhnya ekstrak rimpang alang-alang juga diduga disebabkan oleh proses maserasi yang kurang optimal. Untuk melarutkan zat fenol dalam tanaman harus menggunakan larutan etanol. Menurut Mukhopadhyay (2002) kelarutan zat dalam pelarut tergantung dari ikatan polar dan non polar. Senyawa bersifat polar hanya larut dalam pelarut polar. Senyawa-senyawa polar yang dapat ditarik oleh pelarut etanol $70 \%$ pada rimpang alang-alang tersebut antara lain tanin, fenol, dan flavonoid. Tanin, fenol, dan flavonoid termasuk senyawa polar dan dapat diekstraksi menggunakan pelarut polar (Rahmi, 2007; Sihombing et al., 2012).

\section{Persen Penutupan Gulma}

Luas penutupan atau persen pernutupan gulma (coverage) merupakan perbandingan antara luas tempat yang ditutupi oleh spesies gulma dengan luas total habitat. Persen penutupan dapat dinyatakan melalui proporsi permukaan tanah dalam petakan yang ditutupi oleh proyeksi tajuk tumbuhan.

Berdasarkan hasil pengamatan yang ditunjukkan pada (Tabel 2) terlihat bahwa dosis herbisida berpengaruh terhadap persen penutupan gulma. Tingginya persen penutupan gulma setelah dilakukan aplikasi bioherbisida alang-alang pada konsentrasi yang berbeda menunjukkan adanya penekanan pertumbuhan gulma. Jika hasil pengamatan dibandingkan antara kontrol dengan perlakuan lainnya baik perlakuan $\mathrm{P}_{1}, \mathrm{P}_{2}, \mathrm{P}_{3}$, dan $\mathrm{P}_{4}$ maka akan terlihat persen yang tidak jauh berbeda. Hal ini diduga karena konsentrasi yang diberikan terlalu rendah sehingga memberikan dampak keracunan yang kurang signifikan terhadap pertumbuhan gulma. 
Tabel 2. Persen penutupan gulma pada 0 MSA, 1 MSA, 2 MSA, 3 MSA, 4 MSA, 5 MSA, dan 6 MSA

\begin{tabular}{lccccccc}
\hline \multirow{2}{*}{ Perlakuan } & \multicolumn{7}{c}{ Penutupan gulma (\%) } \\
\cline { 2 - 7 } & 0 MSA & 1 MSA & 2 MSA & 3 MSA & 4 MSA & 5 MSA & 6 MSA \\
\hline $\mathrm{P}_{0}(0 \%)$ & $84,00^{\mathrm{ab}}$ & $74,00^{\mathrm{ab}}$ & $64,00^{\mathrm{ab}}$ & $58,00^{\mathrm{ab}}$ & $55,00^{\mathrm{a}}$ & $54,00^{\mathrm{ab}}$ & $57,00^{\mathrm{a}}$ \\
$\mathrm{P}_{1}(5 \%)$ & $86,00^{\mathrm{abc}}$ & $76,00^{\mathrm{bc}}$ & $67,00^{\mathrm{bc}}$ & $62,00^{\mathrm{bc}}$ & $64,00^{\mathrm{ab}}$ & $70,00^{\mathrm{bc}}$ & $71,00^{\mathrm{ab}}$ \\
$\mathrm{P}_{2}(10 \%)$ & $89,00^{\mathrm{bc}}$ & $80,00^{\mathrm{bc}}$ & $71,00^{\mathrm{bc}}$ & $64,00^{\mathrm{bc}}$ & $64,00^{\mathrm{ab}}$ & $65,00^{\mathrm{abc}}$ & $68,00^{\mathrm{ab}}$ \\
$\mathrm{P}_{3}(15 \%)$ & $98,00^{\mathrm{c}}$ & $88,00^{\mathrm{c}}$ & $79,00^{\mathrm{c}}$ & $71,00^{\mathrm{c}}$ & $74,00^{\mathrm{b}}$ & $80,00^{\mathrm{c}}$ & $85,00^{\mathrm{b}}$ \\
$\mathrm{P}_{4}(20 \%)$ & $73,00^{\mathrm{a}}$ & $61,00^{\mathrm{a}}$ & $51,00^{\mathrm{a}}$ & $46,00^{\mathrm{a}}$ & $46,00^{\mathrm{a}}$ & $48,00^{\mathrm{a}}$ & $49,00^{\mathrm{a}}$
\end{tabular}

Keterangan: Angka-angka pada kolom yang sama dan diikuti huruf yang sama menunjukkan tidak berbeda nyata pada Uji BNT 5\%

\section{KESIMPULAN}

Berdasarkan hasil dan pembahasan yang telah dipaparkan, dapat disimpulkan bahwa aplikasi bioherbisida alang-alang tidak mempengaruhi bobot kering gulma dan persen penutupan gulma. Semakin tinggi konsentrasi ekstrak alang-alang yang diberikan ternyata tidak membuat bioherbisida ekstrak rimpang alang-alang semakin efektif untuk pengendalian gulma.

\section{DAFTAR PUSTAKA}

Kamali, N. R. (2014). Potensi Ekstrak Rimpang Alang-alang (Imperata cylindrica L.) sebagai Bioherbisida Gulma Rumput Kerbau (Paspalum conjugatum Berg.). Universitas Negeri Gorontalo.

Kamsurya, M. Y. (2014). Dampak alelopati ekstrak daun alang-alang terhadap pertumbuhan dan perkecambahan tanaman kacang tanah. In Prosiding Seminar Nasional Basic Science VI. Sains Membangun Karakter dan Berpikir Kritis Untuk Kesejahteraan Masyarakat. Fakultas Matematika dan Ilmu Pengetahuan Alam. Universitas Pattimura.

Markham, K. R. (1988). Cara Mengidentifikasi Flavonoid. Diterjemahkan oleh Padmawinata, K. Bandung: Penerbit ITB.

Mukhopadhyay, M. (2002). Natural Extracts Using Supercritical Carbon Dioxide. New York: CRC Press.

Murrine, E. D. (2010). Pergeseran gulma dan hasil kacang tanah pada tumpanggilir kacang tanah dan jagung. Jurnal Sains dan Teknologi, 3(1), 1-12.

Rahmawasiah. (2015). Efektifitas ekstrak alang-alang dan kirinyuh terhadap pertumbuhan gulma dan pengaruhnya terhadap tanaman kedelai (Glicyne max Merril L). Jurnal Pertanian Berkelanjutan, 4(1).

Rahmi. (2007). Absorbsi fenol pada membran komposit khitosan berikatan silang. Jurnal Rekayasa Kimia dan Lingkungan, 6(1), 28-34. 
Santosa, E., Zaman, S., \& Puspitasari, I. D. (2009). Simpanan biji gulma dalam tanah di perkebunan teh pada berbagai tahun pangkas. Jurnal Agronomi Indonesia, 37(1), 46-54.

Sembodo, D. R. J. (2010). Gulma dan Pengelolaannya. Yogyakarta: Graha Ilmu.

Sihombing. A., Fatonah, S., \& Silviana, F. (2012). Pengaruh alelopati Calopogonium mucunoides Desv. terhadap perkecambahan dan pertumbuhan anakan gulma Asystasia gangetica (L.) T. Anderson. Jurnal Biospecies, 5(2), 5-11.

Sukman, Y. \& Yakup. (2002). Gulma dan Teknik Pengendaliannya. Jakarta: Rajawali Press.

Syakir, M., Bintoro, M. H., Agusta, H., \& Hermanto. (2008). Pemanfaatan limbah sagu sebagai pengendalian gulma pada lahan perdu. Jurnal Littri, 14(3), 107-112. 